\section{Controlling the new proliferation}

\author{
Trade in nuclear technology is increasing. John Stares considers \\ whether the nuclear Non-Proliferation Treaty, six years old last \\ week, can still effectively control the spread of nuclear weapons.
}

\begin{abstract}
DURING the six years since the Treaty on the Non-Proliferation of Nuclear Weapons (NPT) came into force, the peaceful uses of nuclear technology have become much more widespread. With this development has come the increased risk of the misuse of nuclear technology, for military rather than peaceful purposes. Through peaceful nuclear programmes, many countries (in addition to the five nuclear-weapon powers) have accumulated the technical expertise and knowledge, as well as the fissile materials, necessary to develop and manufacture nuclear weapons. In time the number of such countries will grow, and some disarmament experts have predicted that within a few years more countries will in fact "go nuclear". The Indian nuclear test in the spring of 1974 clearly demonstrated that, even for an underdeveloped country, the technological and economic constraints on producing nuclear explosives (whether for peaceful or military ends) that existed a few years have largely disappeared. Is it possible, then, to prevent nuclear-weapon proliferation? If so, is the NPT an effective means of doing so? Or must other means be found?
\end{abstract}

It is certain that the global demand for energy will continue to grow, and that the rate of growth will be highest in the underdeveloped countries. Development requires a plentiful supply of energy-cheap energy-and in the face of shortages and rising prices of other energy sources (oil, for example) the only viable alternative energy source at the moment for many, if not most, underdeveloped countries is nuclear energy. The capital outlays for constructing nuclear power stations may be higher than for oil- or coal-fired power stations, but nuclear fuelling costs are considerably lower than conventional ones, thus making nuclear electricity generation at least competitive in terms of cost with other methods. This is well illustrated by the fact that Iran plans to produce much of its future energy from nuclear power stations, even though it has enormous oil reserves: it is more economical for Iran to sell or conserve its oil than to burn it in power stations.

It is therefore right and proper that nuclear energy should be made available to the underdeveloped countries. This was recognised in the NPT: the Preamble declares that "the benefits of peaceful applications of nuclear technology should be made available for peaceful purposes to all Parties to the Treaty". But any country with its own nuclear power reactor has, on its territory, the raw materials for making nuclear weapons. (It is interesting to note that if a power reactor is operated to produce the cheapest electricity, the plutonium it produces will consist of a mixture of isotopes and will be suitable for making only crude nuclear weapons, not optimally efficient ones.) The number of countries with nuclear programmes is increasing. In 1970 when the NPT became effective, 15 countries were operating power reactors. By 1975 the number had risen to 19 . And if present plans are fulfilled, nearly 30 countries will have their own nuclear power stations by 1980 . The increase in the number of actual reactors is even more dramatic. In 1975 about 170 power reactors were in operation, about two-thirds of them in the nuclear-weapon countries. By 1980 it is creased to more than 400 , and that more than half will be in countries that do not, now, have nuclear weapons.

In theory, the NPT seemed a reasonable system for ensuring that the spread of peaceful nuclear technology did not lead to the proliferation of nuclear weapons. Under the Treaty, all non-nuclear-weapon countries undertook not to manufacture or otherwise acquire nuclear weapons, or indeed any nuclear explosive device, and to permit the application of control procedures, called safeguards, on its nuclear activities "with a view to preventing the diversion of nuclear energy from peaceful purposes to nuclear weapons or other nuclear explosive devices". All parties to the Treaty undertook not to supply fissile material or equipment designed for processing, use or production of fissile material to a nonnuclear-weapon country without safeguards being applied. The Treaty certainly has its weaknesses, perhaps the major one being that it is imbalanced in favour of the nuclear-weapon countries. These were left free to develop and increase their own nuclear arsenals, and were not obliged to submit to safeguards on their nuclear activities.

The Treaty therefore does not ensure the non-proliferation of nuclear weapons, but only seeks to stop their spread to non-nuclear-weapon counestimated that the total will have in-

\section{Sorry, for copyright reasons some images on this page may not be available online}

Can anyone prevent this...

tries. However, if all countries had joined the NPT, the nuclear proliferation problem might now be much less serious than it is: an international system of safeguards covering all nuclear activities (except in the nuclear-weapon countries) would be in operation, and all but five countries would have given up the option of producing nuclear weapons. But several important countries are still not members. This group includes two nuclear-weapon powers, France and China: several other industrial countries, such as Japan (which signed the Treaty in February 1970 but has still not ratified it); and many underdeveloped countries, India being the classic example and others including Brazil, Egypt (which has signed, but not ratified), Israel, Pakistan and South Africa. Many of the countries, industrial and underdeveloped, that remain outside the Treaty are already sufficiently advanced technologically to be able to produce their own nuclear weapons very quickly if ever they decide to do so. It is even believed that some may secretly have done so.

The nuclear exporting countries are clearly worried by this situation and by the possibility that future exports of nuclear materials and equipment might be diverted to military uses. There have been protests at nuclear exports in a number of countries: for example, in the United States there were calls during recent hearings of the Senate Government Operations Committee for an embargo on nuclear exports, and in the 
Canadian Parliament the Opposition has criticised the Government for allowing economic interests to take precedence over more serious concerns about proliferation. Despite these protests, it is unlikely, for economic reasons, that exports will stop. The nuclear-weapon countries have invested huge sums in developing nuclear technology, and they and other industrial countries such as Japan and West Germany look to exports to boost their economies. The United States is reported to earn about $\$ 1$ billion per year from its nuclear shipments; the West German deal to supply Brazil with a complete fuel cycle is worth some $\$ 5$ billion; and the recently announced deal between Canada and South Korea for the supply of a $600 \mathrm{MW}$ reactor involves Canadian, British and US loans totalling $\$ 400$ million.

\section{Concern over misuse}

But although the nuclear exporting countries may be unwilling to halt exports, they are concerned to prevent the misuse of exported technology. During 1975, seven of them-the socalled Nuclear Exporters Group consisting of Canada, France, West Germany, Japan, the USSR, the UK and the USA-held a series of secret meetings on this issue. In January this year they were reported to have reached agreement on new safeguards and control procedures. The exact details remain secret, but according to Dr Fred Ikle, Director of the US Arms Control and Disarmament Agency, in testimony to the Senate Foreign Relations Subcommittee on Arms Control, it is thought that in future, requirements for nuclear exports will involve: acceptance by recipient countries of internationally accepted safeguards drawn up by the International Atomic Energy Agency; assurances by recipient countries that they will not use nuclear exports to make nuclear explosives, for any purpose; provision by importers of adequate security measures to prevent theft or sabotage; and assurances by importers not to transfer materials or duplicates of equipment to third parties without setting similar conditions.

The effect of such measures is not likely to be striking. They may be seen as an attempt to strengthen the NPT, since they are, in essence, similar to the provisions contained in the Treaty itself. In the past, disarmament experts have suggested that membership of the NPT should be demanded as a requirement for receiving nuclear assistance. Apart from the fact that some countries may regard such a move as even more restrictive and discriminatory than the NPT itself, the Group could hardly adopt such a policy when two of its members have not themselves joined the Treaty. The measures could thus be regarded as a "second best" answer to this suggestion. On the other hand, it is even possible to envisage that these measures might weaken, rather than strengthen, the NPT: countries that have not already joined the Treaty may now perceive that there is no pressing need to do so, since they know that the exporting countries are willing to supply assistance under terms that are similar to those of the NPT-but with the important difference that recipient countries will only be required to make a "gentleman's agreement" not to make nuclear weapons, which is very different from undertaking a formal international treaty obligation not to do so.

What must be accepted sooner or later is that it is simply not possible to prevent a country from acquiring the potential to produce nuclear weapons. Applying stringent controls or conditions may slow the process, but any country with a peaceful nuclear programme will inevitably acquire a nuclear-weapon potential in the end. What may be possible-in fact what may be the only answer-is to discourage countries from realising this potential. The only barrier left to the acquisition of a nuclear force, now that the technological and economic constraints have lost their importance, is a political one. For $\mathrm{e}_{\mathrm{e}}$ countries that have joined the NPT, this Treaty represents the barrier: to produce nuclear weapons would be a violation of international commitments. Once countries that have not joined the Treaty acquire a nuclear-weapon potential, they will have the choice whether or not to realise it. This choice will be influenced by political, not technological, considerations, principally the countries' perceptions of their security needs.

The key here is the attitude and behaviour of the nuclear-weapon powers themselves. If they indicate that they do not regard nuclear weapons as essential to security by showing themselves willing to make meaningful reductions in their nuclear arsenals, other countries might well be encouraged to follow their example, and renounce the nuclear option. In Article VI of the NPT, all parties undertook "to pursue negotiations in good faith on effective measures relating to the cessation of the nuclear arms race at an early date and to nuclear disarmament, and on a treaty on general and complete disarmament under strict and effective international control". It can hardly be said that the nuclear weapon powers have lived up to this commitment: the United States and the Soviet Union have been engaged in the Strategic Arms Limitation Talks (SALT) for years, but they have reached no agreements of any significant disarmament value, and the build-up of their nuclear arsenals continues unabated; Britain has also continued to develop its nuclear force, as have France and China, which have not even joined the NPT. An act of faith on the part of these powers, a demonstration that they are serious in their intention to abide by their treaty obligations and in their attempts to achieve nuclear disarmament, would have vastly more impact on world peace and security than any number of secret meetings.

\section{Sorry, for copyright reasons some images on this page may not be available online}

